\title{
Sustainable Development within Planetary Boundaries: A Functional Revision of the Definition Based on the Thermodynamics of Complex Social-Ecological Systems
}

\author{
Bart Muys ${ }^{1,2}$ \\ ${ }^{1}$ Department of Earth and Environmental Sciences, University of Leuven, Celestijnenlaan 200E box 2411, \\ 3001 Leuven, Belgium; E-Mail: bart.muys@ees.kuleuven.be; Tel.: +32 16329726; Fax: +32 16329760 \\ ${ }^{2}$ European Forest Institute, Mediterranean Regional Office, Sant Pau Historic Site, Santa Victoria Pavilion, \\ St. Antoni M. Claret 167, 08025 Barcelona, Spain
}

Submitted: 13 February 2013 | In revised form: 13 June 2013 | Accepted: 19 June 2013 |

Published: 12 July 2013

\begin{abstract}
The dominant paradigm of sustainable development (SD) where the environment is just the third pillar of SD has proven inadequate to keep humanity within the safe operational space determined by biophysical planetary boundaries. This implies the need for a revised definition compatible with a nested model of sustainable development, where humanity forms part of the overall social-ecological system, and that would allow more effective sustainable development goals and indicators. In this paper an alternative definition is proposed based on the thermodynamics of open systems applied to ecosystems and human systems. Both subsystems of the global social-ecological system show in common an increased capability of buffering against disturbances as a consequence of an internal increase of order. Sustainable development is considered an optimization exercise at different scales in time and space based on monitoring the change in the exergy content and exergy dissipation of these two subsystems of the social-ecological system. In common language it is the increase of human prosperity and well-being without loss of the structure and functioning of the ecosystem. This definition is functional as it allows the straightforward selection of quantitative indicators, discerning sustainable development from unsustainable development, unsustainable stagnation and sustainable retreat. The paper shows that the new definition is compatible with state of the art thinking on ecosystem services, the existence of regime shifts and societal transitions, and resilience. One of the largest challenges in applying the definition is our insufficient understanding of the change in ecosystem structure and function as an endpoint indicator of human action, and its effect on human prosperity and well-being. This implies the continued need to use midpoint indicators of human impact and related thresholds defining the safe operating space of the present generation with respect to future generations. The proposed definition can be considered a valuable complement to the recently emerged nested system
\end{abstract}

(C) 2013 by the authors; licensee Librello, Switzerland. This open access article was published under a Creative Commons Attribution License (http://creativecommons.org/licenses/by/3.0/). 
discourse of sustainable development, by offering a more quantitative tool to monitor and guide the transition of human society towards a harmonious relationship with the rest of the biosphere.

Keywords: anthropocene; Brundtland; dissipation; ecocrisis; entropy; exergy; pareto; resilience; self-organization; transition

\section{Introduction}

Sustainable Development as defined by the Brundtland Commission [1]-development that meets the needs of the present without compromising the ability of future generations to meet their own needs -was the hopeful but paradoxical concept which made the 1992 United Nations Conference on Environment and Development (UNCED) in Rio de Janeiro an unprecedented success in global cooperation. Hopeful, because it held the promise of developing the world's majority of people living in poverty. Paradoxical, because it aimed at reconciling the right of development of every world citizen with the global environmental burdens associated with the current development model.

The Brundtland definition was a milestone on the long trajectory of humanity's quest to increase and sustain prosperity in the long term without disrupting the natural resource base on which it has developed (cf. [2]). New to this definition was however the notion of (intergenerational) solidarity between people (e.g., [3]), which adds a social dimension to the economic and environmental dimensions of sustainable development (further denoted as SD).

Unfortunately, this commonly adopted three-pillar model of sustainable development [4] (Figure 1) has not shown sufficient effectiveness for acting within planetary boundaries [5]. The observation that the thresholds for several planetary equilibria have been passed (see e.g., [6]) illustrates the failure of the pillar model, and implies the adoption of an alternative sustainability model. There is increasing understanding that global environmental quality is a nonnegotiable boundary condition for the economic system [7]. Obviously, something more fundamental has to change in the overall strategies of production, consumption and organizing markets [8]. Therefore, a nested sustainability model considering human society and its economy as a subsystem nested in the planetary ecosystem [5,9] (Figure 1) seems a more adequate basis for initiating and implementing a transition towards planetary stewardship [10].

The success of the currently dominating pillar discourse is in its vagueness [11]. Worldwide sustainable development acquired a common connotation of being something important and positive, while leaving large flexibility of attributing very different meanings to it among different segments of society [12]. But in a Rio+20 context of globally dwindling commitment to the cause of SD this vagueness has proven to be at the core of its weakness. The weak scientific fundaments of the definition has led to the often arbitrary selection of sustainability criteria and indicators, and consequently to poor monitoring and compliance. The focus on intergenerational equity got stuck in economic debate on the social discount rate to consider (e.g., [13,14]). Meritorious efforts have been made to build sustainability indicators on more solid scientific grounds (e.g., $[15,16])$, including the concepts of environmental space [17] and ecological footprints [18]. Despite these efforts, SD has become a giant with feet of clay. To revitalize the concept there is a clear need to promote the nested system discourse mentioned above, but this also implies revisiting the definition with more scientific rigor.

In this article we revisit the challenge of SD from the emerging scientific field of complexity science. We propose a more functional and science-based redefinition of SD based on recent advances in complex social-ecological system analysis and supporting the nested systems model of SD. We then discuss the operational advantages and possible pitfalls of the new definition.

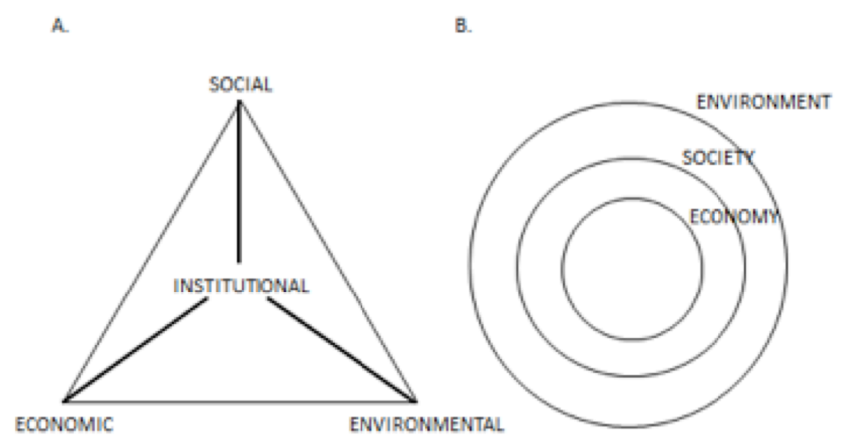

Figure 1. Comparison between the two principal models of sustainable development (after [19]). A. The pillar model; it originally had three pillars (economic, social, environmental) but many authors adopted a fourth institutional pillar. B. The nested systems model; the economy is at the service of human society, which in turn needs to operate within the biophysical boundaries of the planetary ecosystem [5]. 


\section{Background and Scientific Basis for a New Definition}

\subsection{Fundamental Changes in the Social-Ecological System}

The relationship of humanity with nature changed fundamentally between the onset of the Holocene period about 12,000 years ago and today. Human societies developed from small groups of hunter-gatherers through larger farming/agricultural communities to global urban-industrial society $[8,20]$. Larger complex societies led to a more efficient buffering of external and internal disturbances and thus to more prosperity and well-being. From an energetic point of view, this evolution of mankind from a modest role in the food web to the prominent ecosystem engineer was characterized by a regime shift in metabolic profile, characterized by an increase in per capita daily caloric energy consumption by more than a factor of $50[8,21]$. This was the consequence of agricultural and industrial revolutions, which complemented manpower with horsepower and later machine power. This improved the human condition to such an extent that an increase in human population with by a factor of more than 10,000 occurred. The resource needs to sustain such a large complex system have grown far beyond what nature or agricultural production can provide, and non-renewable resources external to the biosphere (e.g. petrol and uranium from the geosphere) have been discovered and are being exploited to meet these needs [22]. These fundamental differences in the energetic relationships to nature between hunter/gatherer, agrarian, and industrial-urban societies are visualized in Figure 2.

\subsection{The Ecosystem Exergy Concept}

In section 2.1 the crucial role of energy flows to sustain complex human societies was explained. Thermodynamics is therefore a suitable discipline to describe the macroscopic behavior of complex living systems. Early scholars including Lotka, Schrödinger and Prigogine have developed the basics for thermodynamics of such open systems. Schneider and Kay [23] formulated the ecosystem exergy concept (exergy is useful energy able to do work; it can be consumed in contrast to energy; it is often what people mean when using the word energy; see [24] for a review) as a holistic descriptive model of the behavior of complex living systems far from thermodynamic equilibrium. It basically comprises four essential elements: a) Ecoystems are open systems exposed to exergy fluxes (mainly solar radiation). b) Like a dam in a river, ecosystems accumulate part of that incoming exergy to increase their own exergy content (Schrödinger's order from disorder premise, [25]). c) Ecosystems with higher exergy content are more effective dissipative structures, i.e. dispose of a larger buffering capacity against destructive exergy fluxes such as radiation, wind, rain, and nutrient and sediment loss. Buffering is defined here as any physical or chemical activity at the disposal of a system to reduce a gradient imposed on it (see [23]). Forest ecosystems for example buffer against sunlight and destructive rains with their canopy structure, and against the leaching of nutrients and erosion with their root network; the buffer capacity depends on the quality of the filter, i.e. the density and equal distribution of leaves and roots. d) It is crucial to understand that improved buffering in an ecosystem leads to improved chances on survival and thus to evolutionary advantage, and is as such a motor of evolution: ecosystems improve and keep their capacity to create order and dissipate exergy by Darwinian selection and transfer of genetic information to subsequent generations (order from order).

In this model, exergy maximization is considered a goal function of ecosystem development, which leads, in the absence of large disturbances, to increased control over energy and matter flows. This model concurs with the ecosystem succession model of Odum [26] and Bormann \& Likens [27], and is supported by thermal remote sensing observations [28-30]. It does not conflict with the second law of thermodynamics, because the local increase of exergy in open dissipative systems leads to more effective dissipation and, as a matter of fact, to an increase of entropy of the global system, in which the ecosystem is embedded [31].

Social scientists (e.g., [20,32]) independently came to a similar insight that the thread of human evolution is towards larger societies with more complex institutional organizations leading to stronger collective protection against human suffering of all kinds. This remarkable parallel in structure and function between ecosystems and human systems is illustrated in Table 1 . The ecosystem exergy concept proves to be a powerful model to describe the relationship between the structure and function that ecosystems and human societies have in common with Carnot's law for closed systems: the higher the exergy availability of a system, the higher its potential to perform work. Complex systems can basically: 1) store exergy and keep it available for one or more of the following uses (storage also implies a risk of loss, e.g. forest biomass accumulation leading to increased fire loss); 2) use it for maintenance (as survival depends on it, it is typically a priority allocation); 3 ) for buffering (as it offers collective long-term survival perspectives, it is an important driver of co-evolution for the different elements of the system); or 4) for luxury consumption (this is exergy consumption not leading to one of the former two outcomes, and that in an evolutionary perspective will ultimately get eliminated by selection pressure). Buffering leads to better fitness of the system and is therefore a fundamental principle of self-organization. We therefore name our world where ecoystems and human systems co-exist bufferworld. 


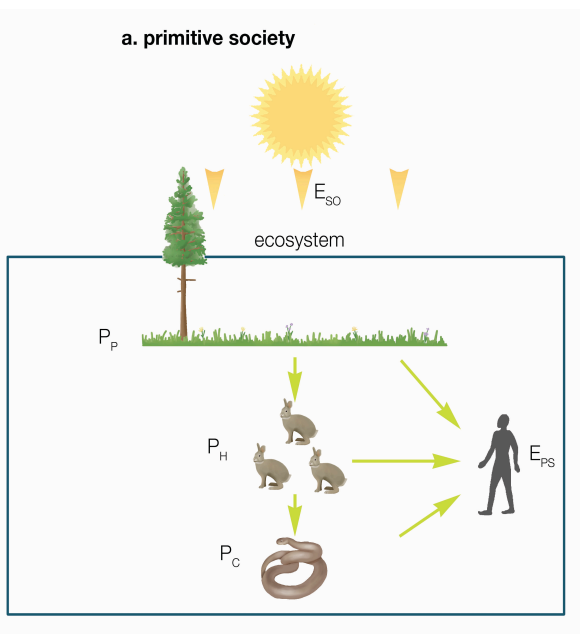

b. agrarian society

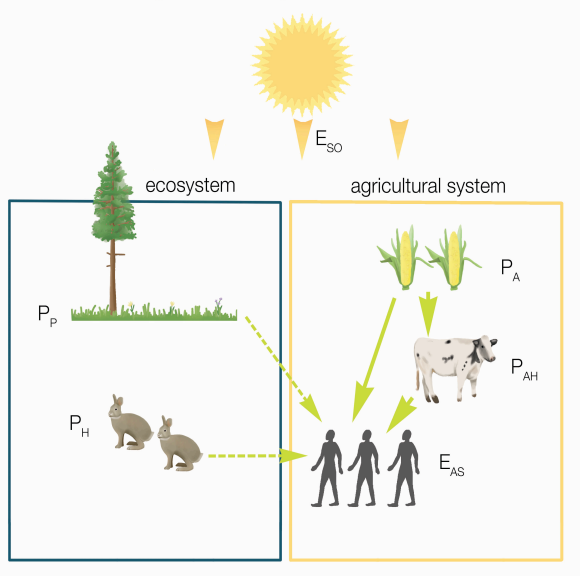

c. industrial-urban society

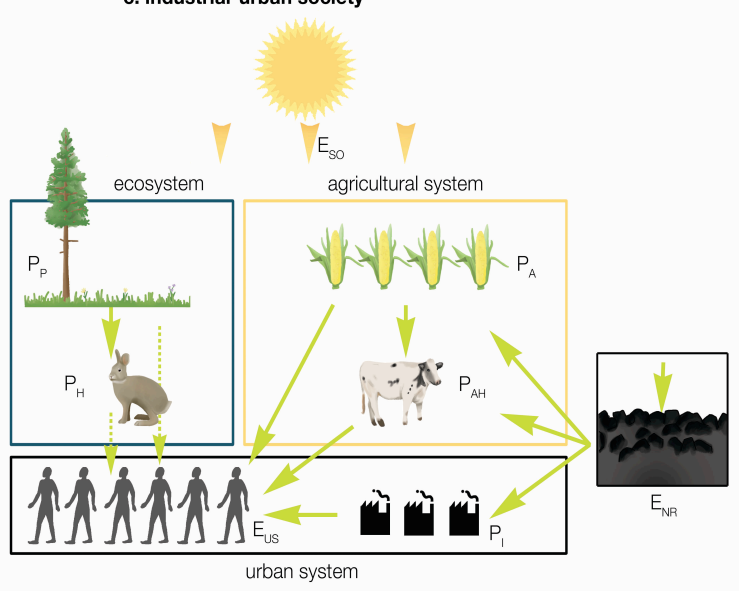

Figure 2. A simplified representation of the energetic relationships between mankind and nature in a) a primitive society; b) an agrarian society; and c) an industrial-urban society (after [33]). Legend of symbols: $\mathrm{E}_{\mathrm{so}}=$ incoming solar energy; $P_{p}=$ primary production of plant biomass in the ecosystem; $\mathrm{P}_{\mathrm{H}}=$ production of herbivores in the ecosystem; $P_{c}=$ production of carnivores in the ecosystem; $E_{P S}=$ energy needs of the primitive society; $P_{A}=$ primary production in the agricultural ecosystem; $P_{A H}=$ production of herbivores in the agricultural ecosystem; $\mathrm{E}_{\mathrm{AS}}=$ energy needs of the agrarian society; $E_{\mathrm{NR}}=$ non renewable energy sources; $P_{I}=$ industrial production; $E_{u s}=$ energy needs of the urban society. Dashed, resp. dotted lines indicate fluxes of relatively decreasing importance, which in absolute terms may be increasing. Note that through the evolution from primitive over agrarian to industrial-urban society the human population increases, the area of (semi-)natural systems decreases in favor of agricultural and urban land; wildlife decreases and large predators become extinct.

\section{Proposal for a New Definition}

\subsection{The Anthropocene}

Human communities form part of the biosphere and have always been heavily dependent on resources extracted from the ecosystem for their exergy provision, and on other ecosystem services for their buffering (Figure 2). In recent history humans discovered and used extensively more concentrated exergy sources exogenous to the biosphere (coal, petrol, natural gas and uranium from the geosphere). Apart from the risk of depletion, their consumption causes toxic or climate forcing emissions, which provoke disturbances in the biosphere. Meanwhile their use greatly increases the power of humans to modify the biosphere. As a consequence, increasing amounts of land gradually or abruptly change from the sphere of nature dominion to increasing human dominion $[17,34,35]$. It makes the protective vegetation canopy thinner and scarcer, undermining its buffering capacity for light, heat, wind, rain and dust. Human efforts to concentrate solar exergy in useful target crops through intensive agriculture, forestry and biocide use are leading to an overall simplification of the biosphere (see e.g., [36]). Human development-induced changes in biogeochemistry and atmospheric composition at planetary scale are large enough to consider the onset of a new geological era, called anthropocene [37].

A thermodynamic interpretation of the anthropocene would be that the human society is increasingly behaving as a separate system, which means that it increases its order at the expense of the order in the biosphere. The current development of human society is causing a tradeoff with entropy production in its environment, which is threatening the buffering capacity of the biosphere in the long term. Anthropogenic entropization of the biosphere is the essence of the ecocrisis in bufferworld. Considering the heterotrophic metabolism of humans and the large dependence of human society on ecosystem services [38] (Figure 3), it must be emphasized that human society is a subsystem nested in the biosphere. It is not viable without the ecosystem, while the ecosystem is viable without human society. As a consequence, this evolution seems more worrisome for mankind than for the biosphere in general. 
Table 1. The ecosystem exergy model of Schneider \& Kay [24] as the universal goal function of complex self-organizing systems, here applied to ecosystems and human society, illustrating the analogy in structure and function between the two systems.

\begin{tabular}{|c|c|c|}
\hline & Ecosystems & Human Society \\
\hline Goal function & $\begin{array}{l}\text { Max[buffer exergy } \\
\text { flows] through } \\
\text { max[exergy content] }\end{array}$ & $\begin{array}{l}\text { Max[buffer exergy } \\
\text { flows] through } \\
\max [\text { exergy content] }\end{array}$ \\
\hline $\begin{array}{l}\text { Main exergy } \\
\text { source }\end{array}$ & Solar exergy & $\begin{array}{l}\text { Ecosystems, fossil } \\
\text { fuels }\end{array}$ \\
\hline $\begin{array}{l}\text { Exergy } \\
\text { storage }^{1}\end{array}$ & $\begin{array}{l}\text { Biomass, genetic } \\
\text { diversity, diaspores, } \\
\text { foodwebs and other } \\
\text { ecosystem structures }\end{array}$ & $\begin{array}{l}\text { Food reserves, } \\
\text { houses, money, social } \\
\text { and institutional } \\
\text { structures, other } \\
\text { capital and assets }\end{array}$ \\
\hline $\begin{array}{l}\text { Memory and } \\
\text { information } \\
\text { transfer }^{2}\end{array}$ & DNA & $\begin{array}{l}\text { DNA, oral and written } \\
\text { information, bits and } \\
\text { bytes }\end{array}$ \\
\hline $\begin{array}{l}\text { Exergy } \\
\text { dissipation } \\
\text { (Buffer } \\
\text { function) }\end{array}$ & $\begin{array}{l}\text { Buffering against } \\
\text { sunlight, temperature } \\
\text { change, nutrient loss, } \\
\text { water runoff, sediment } \\
\text { loss, wind damage }\end{array}$ & $\begin{array}{l}\text { Shelter against } \\
\text { climatic extremes, } \\
\text { internal and external } \\
\text { threats in terms of } \\
\text { conflict, hunger, } \\
\text { disease, natural and } \\
\text { technical disasters }\end{array}$ \\
\hline
\end{tabular}

${ }^{1}$ See [25], supplementary material S4 for a discussion on the exergy content of information. A tree seed has much lower exergy content than an adult tree weighing 5 tonnes, but it holds the potential to accumulate a similar amount. Also, money is an important carrier of exergy, which can be exchanged at any time against exergy for maintenance or to perform buffer work.

2 Memory and information transfer are essential to share successful experiences of exergy accumulation and exergy buffering with conspecifics of the next generation. Plants transfer information mainly through DNA, while vertebrate animals show plenty of learning methods in addition to genetic transfer. Although the hereditary intelligence of humans is not very much higher than that of apes, the revolutions of non-genetic information transfer through oral and written communication have boosted their progress in exergy capture and exergy buffering.

\subsection{The Definition}

Based on the former, we define Sustainable Development as the increase of the exergy content and exergy buffering of human society, not provoking a measurable decrease of exergy content and exergy buffering of the ecosystem. This scientific definition is valid and applicable for social-ecological systems at different scales of time and space, e.g. over a decade at the level of a local community with its surrounding landscape, or on an annual basis at the level of the world community with its global natural resources. This can be easily translated into everyday language as the increase of human prosperity (exergy content) and human well-being (exergy buffering) without the loss of ecosystem structure (exergy content) and ecosystem functioning (exergy buffering). In short it is development that does not degrade the biosphere. It is important to observe that both the human and the ecosystem side of the definition have a structural and a functional component: human prosperity and ecosystem structure and composition as the structural component (exergy content, order); human well-being and ecosystem function as the functional component (exergy dissipation, bufferwork). As mentioned earlier exergy content and exergy dissipation are related but not linearly: exergy content is a necessary condition to perform bufferwork (no well-being without capital), but inversely, exergy content has many options, as it can be used as a reserve, maintenance, luxury consumption or buffering. Buffering can also be the mere consequence of the presence of dissipative structures. Especially on the human side, the build-up of capital with a limited increase in overall societal buffering capacity has been common in the history of mankind, and has been extensively debated in classical socio-economic literature. Indicator selection should therefore include both prosperity (economic pillar) and well-being (social pillar) aspects to measure human development.

The foregoing has made clear that increasing the prosperity and well-being of human society often implies the extraction of resources from ecosystems, emissions into ecosystems, and competition for space, and will thus often be at the expense of their structure and function. These trade-offs between human society and ecosystems suggest the existence of a set of optimal solutions as a compromise between human development and ecosystem development. Technically speaking, the new definition is the result of an optimization exercise, that is searching for efficient solutions along a Pareto front formed by the trade-off between human prosperity and well-being and ecosystem structure and function (Figure 4). In Figure 4 we can see how sustainable development can move the system to improved human prosperity and well-being under a status quo or an improvement of the ecosystem structure and function, until it reaches a new state (the Pareto efficient solution) where further human development would unavoidably lead to ecosystem degradation. It becomes obvious that sustainable development (development without the loss of ecosystem structure and function) is a difficult challenge, and does not seem achievable with technical measures alone or isolated project-wise actions within the current institutional context, but would need a large societal transition accompanied by a global institutional reform $[8,41]$. Such a transition should lay the basis for a more harmonious co-evolution between humans and ecoystems as a unified social-ecological system inhabiting the biosphere. Possible elements of such a transition are captured by the proposed definition: an increase of resource efficiency (creating more prosperity and well-being with less input or output 


\section{ECOSYSTEM $\Rightarrow$ ECOSYSTEM SERVICES $\Rightarrow$ SOCIAL SYSTEM}

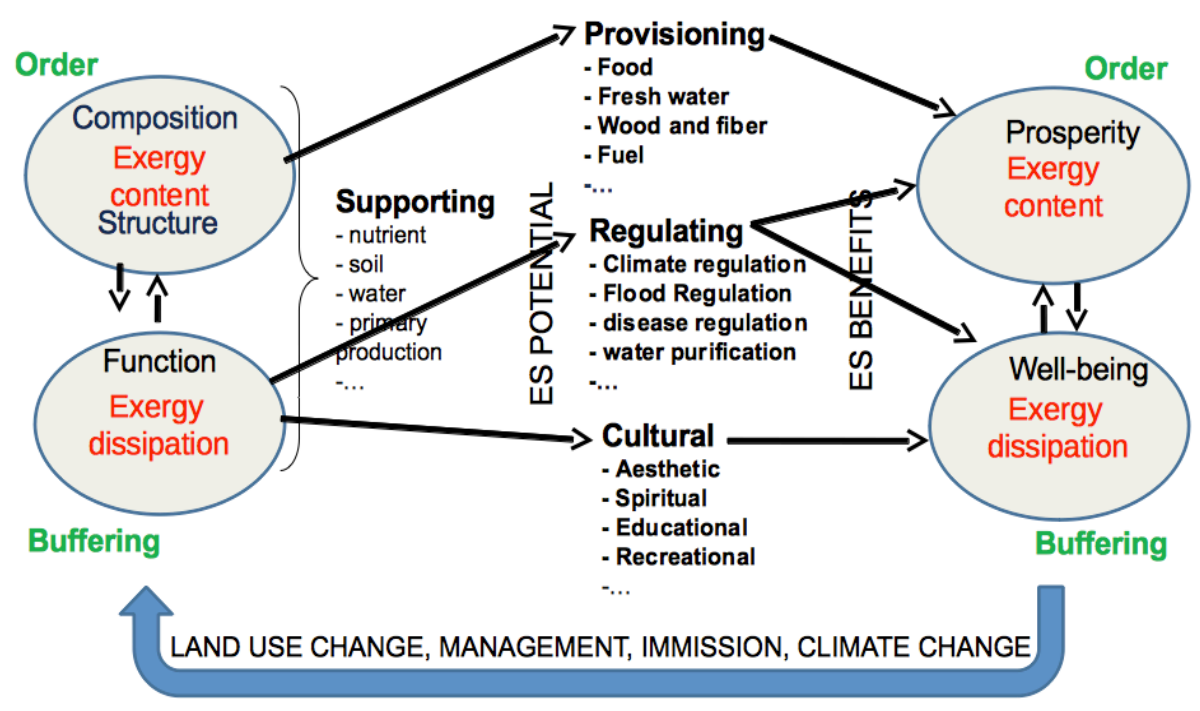

Figure 3. Conceptual scheme showing the relationships between ecosystems and social systems as closely interlinked subsystems of the overarching social-ecological systems occurring in the biosphere. Both subsystems develop a structural/compositional component (exergy content), which provides exergy to their functional component (buffering). The composition, structure and function of the ecosystem offer a potential source of ecosystem services to human society $[39,40]$, which may use the ecosystem service benefits to increase prosperity (the economic pillar of development) and well-being (the social pillar of development). The feedback arrow at the bottom illustrates that ecoystems are heavily shaped by deliberate and unintended human influences.

a)

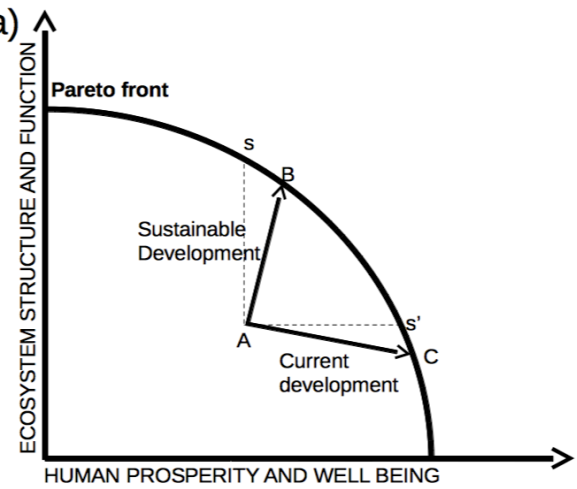

b)

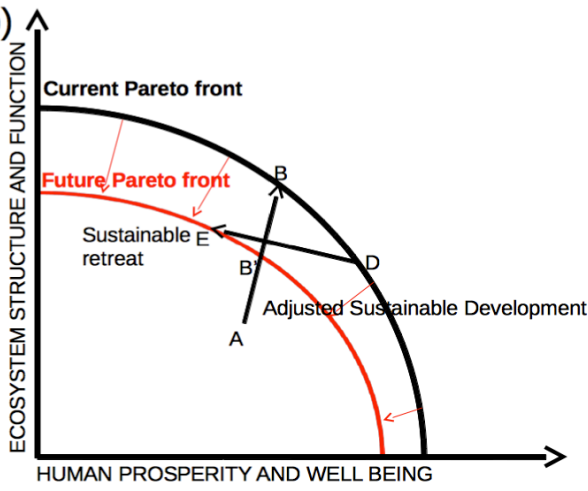

Figure 4. Sustainable development as an optimization exercise between human goal functions and ecosystem goal functions. a) The Pareto front is the set of efficient solutions (it means solutions where further human development would unavoidably lead to ecosystem damage, and vice versa). Trajectories from a present non Pareto-efficient situation $A$ to $B$ and $C$ show the main development options. Trajectory $A B$ evokes the challenge of sustainable development, increasing human goals without decreasing ecosystem goals. All trajectories between As and As' are Pareto efficient and therefore sustainable. Trajectory AC shows the current development trend, which is outside the trajectory range between As and $\mathrm{As}^{\prime}$ and therefore unsustainable, given that it increases human goals while decreasing ecosystem goals. b) As a consequence of anthropogenic environmental degradation the current Pareto front may shrink to a future Pareto front with lower potential exergy buffering for both sub-systems. Under such a regime shift (cf. Section 5.2) an effort of sustainable development $A B$ will end up as an inferior adjusted sustainable development AB' (cf. [41]). Lovelock [42] considers that we are now already in a situation where further development without environmental damage is no-longer possible (this means that we are on or above the Pareto front) and where the shrinking resource base urges for a so-called sustainable retreat to a lower future Pareto front, which can be visualized by the trajectory DE. 
related impact on the structure and function of the ecosystem), the replacement of overconsumption by a more frugal lifestyle (decreasing ecosystem impacts caused by prosperity that does not contribute much to well-being), and setting safeguards on vital ecosystem structures and functions (implementing caps on human development where it directly affects vital ecosystem structures and functions).

This definition is transparent and functional. Anchored in the laws of thermodynamics it allows the selection of quantitative indicators (see Section 4).

\section{Indicators and Application}

Rather than presenting a concrete indicator set, some guiding principles are formulated as to the selection and processing of indicators based on the new definition of SD. Sustainability is evaluated for a given social-ecological system with defined system boundaries over a certain period of time, by comparing human development (change of prosperity and well-being over this time period) with ecosystem development (change in structure and function over this time period), which can be written as:

$$
\frac{I_{P W, t_{1}}-I_{P W, t_{0}}}{I_{E S F, t_{1}}-I_{E S F, t_{0}}}
$$

where $I_{P W}$ is the selected indicator for human prosperity and human well-being (remember that, thermodynamically speaking, this corresponds respectively to the exergy content and exergy buffering of the human system), $\mathrm{I}_{\mathrm{ESF}}$ the selected indicator for ecosystem structure and ecosystem function (remember that these are respectively the exergy content and exergy buffering of the ecosystem), $t_{0}$ and $t_{1}$ the start and end of the considered evaluation period.

Basically the sustainability check of equation (1) has four possible outcomes:

- Increase in numerator and denominator: sustainable development;

- Increase in numerator and decrease in denominator: unsustainable development;

- Decrease in numerator and increase in denominator: sustainable retreat;

- Decrease in numerator and decrease in denominator: unsustainable stagnation.

The magnitude of the obtained ratio in comparison with values from other regions or time periods allows interpretation of how sustainable or unsustainable the observed development is. This is possible for contemporary studies (e.g. annual monitoring of human prosperity and well-being and ecosystem structure and function in a Brazilian catchment after inaugurating a new dam), retrospective analysis of human development in the past (e.g., calculating sustainability in Roman and Byzantine periods based on forest resource modeling modulated by population density estimates from archaeological evidence for an ancient city excavated in Turkey), or prospective analysis of human development in the future (e.g., modeling the biodiversity loss caused by climate change for different IPCC SRES scenarios based on scenarios of human development, see [43]).

As such, this approach sets a framework for continuous monitoring and improvement, rather than proposing fixed sustainability thresholds. This makes sense, because as a consequence of regime shifts, which are inherent to complex social-ecological systems (Figure $4 \mathrm{~b}$ and Section 5.2), sustainable development is a moving target. But Rockström et al. [6] argue that to avoid unwanted regime shifts in the biosphere, thresholds must be placed on vital biophysical conditions that determine the safe space within which humans can operate. Putting a minimum threshold level on ecosystem exergy content and dissipation is perfectly possible within the here proposed framework.

Note that numerator and denominator are not necessarily in the same units, unless exergy analysis would be applied. In practice analysts may want to work with proxy indicators having different units, e.g., Gross Domestic Product (GDP per capita in monetary units, \$ per capita per annum) for human prosperity and well-being (in fact, the GDP per capita, also called the standard of living is not a proxy of the exergy content but of the annual exergy inflow in the human system, which can be used for maintenance, increase in prosperity, and increase in well-being) and e.g., protected area (in $\mathrm{km}^{2}$ ) or free Net Primary Production (fNPP, in ton per ha per annum, cf. $[44,45]$ ) for ecosystem structure and function (in fact, the fNPP is not a state indicator but measures the fraction of the annual increase in ecosystem exergy content that is not extracted by humans), or may want to work with dimensionless composite indicators like e.g. Inequality Adjusted Human Development Index (cf. [46]), Genuine Progress Indicator (cf. [47]) or Gross National Happiness (cf. [48]) for human prosperity and well-being (although the latter already includes ecosystem fitness).

A large remaining challenge is the development of indicators for ecosystem structure and function. In fact, the effects of human activity on ecosystem composition, structure and function are, thus far, poorly understood. As a consequence, indicators and monitoring instruments for ecosystem structure and function are still largely underdeveloped, and multitemporal information of ecosystem trends are hardly available. According to Rosen [49] it is a big asset of ecosystem exergy analysis that it can measure the increase in disorder in ecosystems associated with human environmental impact. Odum [27] was one of the first to propose an indicator set 
for measuring ecosystem maturity based on ecosystem thermodynamics. Several other indicators measuring the degree of self-organization, integrity or naturalness of ecosystems have been proposed ever since. Bendoricchio and Jørgensen [50] came up with an elegant formula to calculate the exergy content of ecosystems including the exergy content included in its biodiversity. This formula was criticized as thermodynamically incorrect (e.g., [51]), but was later recycled as a calculation of eco-exergy, a proxy for ecosystem exergy content useful for accounting purposes. Others developed indicators for solar exergy dissipation by ecosystems, based on the evaluation of their energy balance (e.g., $[30,52])$. There is also a long tradition of trying to give monetary value to ecosystems and ecosystem services, which is potentially a good proxy of ecosystem exergy content and buffering. But it is important to recognize the important limitations of economic valuing, including the poor methodological development of valuing biodiversity and biodiversity function, and the serious limitations of the ceteris paribus principle of partial equilibrium when upscaling value to the global level (cf. the criticized global valuing of ecosystem services like pollination by [53]). For the time being, end point indicators of changes in ecosystem state and function in the denominator of equation (1) can be replaced by mid-point indicators of human input-related (resources use) and output-related (emissions) impacts, or inversely, of human efforts towards sustainability, like efficiency indicators. Another complication of selecting indicators is the problem of spillover and double counting. Spill-over happens when a selected indicator does not include all aspects of human or ecosystem development and, as a consequence, shows externalities. A concrete example is the use of forest transition [54] as a sign of sustainable development. The forest index of countries typically evolves from a trend of more people, less trees in the early stages of development (positive numerator and negative denominator in our formula = unsustainable development) to a trend of more people, more trees in later stages of development. The explanation of this geographical theory is however leakage and spillover: in later stages of development countries increasingly thrive on imported carrying capacity (wood imports from neighboring countries with a lower standard of living is exporting the deforestation problem, see [55], and on converting the energy system from wood-fuel to fossil fuel turning the input-related environmental impact into an output-related environmental impact. Double counting is a typical problem of using indicator baskets. In the land use impact method used in Garcia et al. [56] for example, Leaf Area Index is used as an indicator of ecosystems structure (exergy content) and soil erosion is used as an indicator of ecosystem function (exergy dissipation), but the soil erosion buffer is a direct consequence of the presence of a large leaf area.

\section{Discussion}

\subsection{Focus and Functional Strength of the New Definition}

The revised definition of SD has a more solid scientific background than earlier ones, which facilitates the selection of indicators that are not arbitrary, but that quantify the exergy content and exergy dissipation of both human and ecosystem subsystems of the socialecological system.

The system boundaries for global SD assessment are set to the biosphere, the vital space for life on earth (or to part of the biosphere for SD assessment at a smaller geographical level). The geosphere is excluded, which means that in contradiction to some impact methods (cf. [57]) the use of fossil fuels or ores is not considered an environmental burden, but obviously the impact on the ecosystem of careless extraction and emissions as a consequence of its use are considered a burden.

Different from the Brundtland definition, the revised definition does not focus on the trade-off between present and future generations of humans, but rather on present, past and future trade-offs between humans and ecosystems. This is similar to the definition recently published by [5]. One could say that this approach is less anthropocentric than the Brundtland definition and other definitions along the line of the pillar discourse, as it proposes equal interests for humans and ecosystems. Since humans depend on ecosystems, the state of the ecosystem partly reveals the fate of future generations of humans. But only two of the nine planetary thresholds that [6] use to determine the safe operating space of humans to avoid a catastrophic shift in the planetary metabolism are directly related to ecosystem structure and function (biodiversity loss, change in land use), while the seven others (climate change, ocean acidification, stratospheric ozone depletion, nitrogen and phosphorus cycles change, global freshwater use, atmospheric aerosol loading and chemical pollution) are, albeit interlinked with ecosystems, physical-chemical state and rate variables that will affect both humans and ecosystems of the future. This means that planetary stewardship (see [58]) needs to consider effects of present development on both present ecosystem structure and function and future human and ecosystem development. In that sense, the indicator set linked to the denominator of equation [1] should not be limited to the structure and function of the ecosystem, but it is recommended that it includes also physical/chemical state indicators of the overall social-ecological system.

\subsection{Determinism versus Stochasticity}

The exergy concept shows several parallels with the ecosystem succession theory of Odum (1969) [26], which has been criticized for being unidirectional and deterministic. In reality stochastic phenomena make the behavior of social-ecological systems largely unpre- 
dictable, and disturbances have to be considered inherent to the existence of ecosystems. Kay [59] showed that the ecosystem exergy concept is not in contradiction with chaos theory and the occurrence of alternative stable states [60]. The panarchy model for the ecological and social systems of Gundersen \& Holling [61] very satisfactorily links the deterministic components of ecosystem thermodynamics with the stochastic aspects of chaos theory into one single theory. By adding an extra dimension of resilience to the trend of exergy increase during a process of self-organization, they are able to clarify how disturbance is inherent to complex systems: increasing order and fine-tuning the bufferwork to the small recurrent disturbances, the system is losing resilience, and becomes fragile and sensitive for catastrophic shift to a different state. Figure 5 illustrates how the existence of such stable states in both human systems and ecosystems complicates the goal setting of sustainable development.

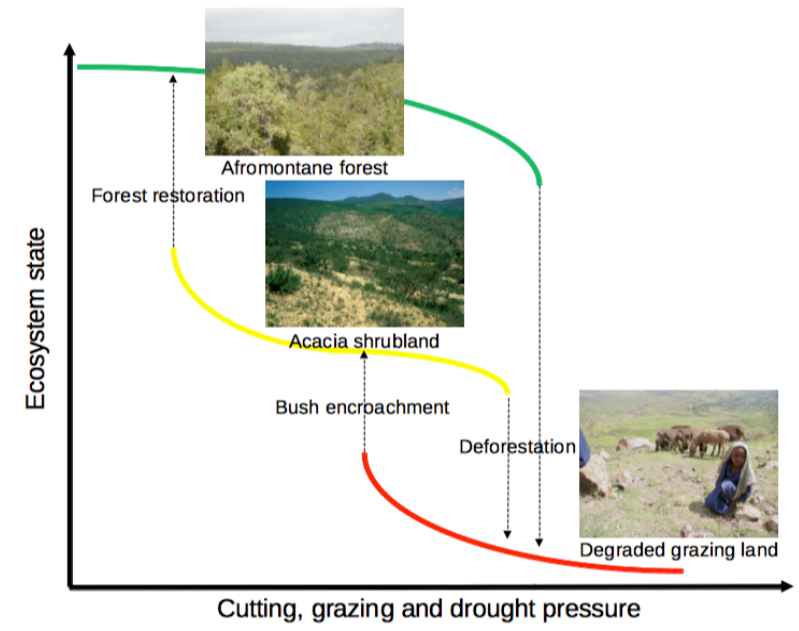

Figure 5. Example based on observations from [62] of an extremely non-linear response of ecosystems to pressures caused by human development, giving existence to alternative stable states and making sustainable development a moving target. The Afromontane Forest of semiarid northern Ethiopia is well buffered against the effects of human development, but beyond a certain threshold the forest collapses and changes into degraded grazing land. If forest restoration efforts are made, it appears that restoration only becomes possible at much lower pressures than the collapse occurred, and restoration does not directly result in the recuperation of the original vegetation but in a bush state with lower ecosystem services than the original forest. This phenomenon of non-reversibility is called hysteresis, and is a typical indication of alternative stable states.
The panarchy theory is a good basis to explain the efforts needed for a transition towards sustainable development. The loss of resilience in mature complex systems is congruent with the so-called institutional lock-ins described in transition theory [63]. Transition only boosts when innovation niches are created through institutional reforms focusing on the increased resilience of society and ecosystems [64-66]. This means that the transition pathway towards sustainable development could pass through phases where the order or buffer capacity of the human society temporarily decreases, while the resilience increases. In order to evaluate the success of a transition process, it is therefore recommended that monitor resilience indicators of the social-ecological system as a whole is also carried out, in addition to equation (1).

\section{Conclusion}

The proposed definition of sustainable development completes the nested systems discourse on sustainability, which considers that socio-economic development needs to operate within the safe operating space defined by planetary boundaries. It is a science-based functional definition, which facilitates the selection of indicators, and the development of simple measuring tools for the evaluation of complex social-ecological systems. It can serve as an operational support to assess the progress along the transition pathway towards a sustainable society. It hopes to contribute to moving sustainable development away from a fuzzy contradiction in terms towards an objective optimization problem between the human system and the ecosystem, two strongly interlinked sub-systems, nested in the overall socialecological system, and showing fundamentally similar patterns and processes of structures and functions for buffering. It finally holds an active invitation for human society to make a transition to more harmonious development as part of the socialecological system rather than autonomous development at the expense of the ecosystem.

\section{Acknowledgements}

The author wrote this article in the context of the project GOA/13/004 "Approaching patterns of nature-society interactions in regional development. An interdisciplinary dialogue between past and present in the region of Sagalassos" financed by the $\mathrm{KU}$ Leuven Research Fundand with support of the KLIMOS R\&D platform on climate and development, financed by VLIR and Belgian Development Cooperation. 


\section{References}

1. World Commission on Environment and Development (WCED). Our common future: The Brundtland report. Oxford, UK: Oxford University Press; 1987.

2. Diamond J. Collapse: How societies choose to fail or succeed. New York, NY, USA: Penguin Group; 2006.

3. Howarth RB, Norgaard RB. Environmental evaluation under sustainable development. The American Economic Review. 1992;82(2):473-477.

4. Meadowcroft J. Sustainable Development: A New(ish) Idea for a New Century? Political Studies. 2000;48:370-387.

5. Griggs D, Stafford-Smith M, Gaffney O, Rockström J, Öhman MC, Shyamsundar P, Steffen W, Glaser G, Kanie N, Noble I. Sustainable Development Goals for People and Planet. Nature. 2013;495(7441): 305-307.

6. Rockström J, Steffen $W$, Noone $K$, Persson A, Chapin FS, Lambin EF, Lenton TM, Scheffer M, Folke C, Schellnhuber HJ, Nykvist B, de Wit CA, Hughes T, van der Leeuw S, Rodhe H, Sörlin S, Snyder PK, Costanza $R$, Svedin $U$, Falkenmark $M$, Karlberg $L$, Corell RW, Fabry VJ, Hansen J, Walker B, Liverman D, Richardson $\mathrm{K}$, Crutzen P, Foley JA. A safe operating space for humanity. Nature. 2009;461(7441):472-475.

7. Stevenson G, Keehn B, editors. I Will if You Will: Towards Sustainable Consumption London, UK: SDC/NCC; 2007.

8. Haberl $\mathrm{H}$, Fischer-Kowalski $M$, Krausmann $F$, Martinez-Alier J, Winiwarter V. A socio-metabolic transition towards sustainability? Challenges for another Great Transformation. Sustainable Development. 2011;19(1):1-14.

9. Giddings B, Hopwood B, O'Brien G. Environment, Economy and Society: Fitting them together into Sustainable Development. Sustainable Development. 2002;10(4):187-196.

10. Muys $B$, Van Acker $K$, Vandevyvere $H$, Mathijs E, Marx A, Van Lipzig N, Jones PT. Transition to a Climate Neutral Society: From Innovation Niches to Institutional Reform. KU Leuven Euroforum Policy Paper. 2013.

11. Redclift M. The multiple dimensions of sustainable development. Geography. 1991;76(1):36-42.

12. Schellnhuber HJ, Kropp J. Geocybernetics: Controlling a Complex Dynamical System Under Uncertainty. Naturwissenschaften. 1998;85:411-425.

13. Howarth RB, Norgaard RB. Intergenerational transfers and the social discount rate. Environmental and Resource Economics. 1993;3(4):337-358.

14. Stern N. The Economics of Climate Change: The Stern Review. Cambridge, UK: Cambridge University Press; 2007.

15. Meadows $\mathrm{DH}$. Indicators and information systems for sustainable development. A report to the Balaton Group. Hartland Four Corners, VT, USA: The
Sustainability Institute; 1998.

16. Bossel H. Indicators for Sustainable Development: Theory, method, applications. A report to the Balaton Group. Winnipeg, Canada: International Institute for Sustainable Development (IISD); 1999.

17. Spangenberg JH. Environmental space and the prism of sustainability: Framework for indicators measuring sustainable development. Ecological Indicators. 2002;2(3):296-309.

18. Wackernagel M, Onisto L, Bello $P$, Callejas Linares A, López Falfán IS, Méndez Garća J, Suárez Guerrero AI, Suárez Guerrero MG. National natural capital accounting with the ecological footprint concept. Ecological Economics. 1999;29(3):375-390.

19. Waas T, Hugé J, Verbruggen A, Wright $T$. Sustainable Development: A Bird's Eye View. Sustainability. 2011;3(10):1637-1661.

20. Johnson AW, Earle TK. The Evolution of Human Societies: From Foraging Group to Agrarian State. Palo Alto, CA, USA: Stanford University Press; 2000.

21. Cook E. Flow of energy in an industrial society. Scientific American. 1971;224(3):134-144.

22. Crosby A. Children of the sun: A history of humanity's unappeasable appetite for energy. New York, NY, USA: Norton; 2006.

23. Schneider E, Kay J. Life as a manifestation of the second law of thermodynamics. Mathematical and Computer Modelling. 1994;19(6-8):25-48.

24. Dewulf J, Van Langenhove $H$, Muys B, Bruers S, Bakshi BR, Grubb GF, Paulus DM, Sciubba E. Exergy: Its potential and limitations in environmental science and technology. Environmental Science \& Technology. 2008;42(7):2221-2232.

25. Schrödinger E. What is life? Cambridge, UK: Cambridge University Press; 1944.

26. Odum EP. The strategy of ecosystem development. Science. 1969;164(3844):262-270.

27. Bormann FH, Likens GE. Pattern and process in a forested ecosystem. New York, NY, USA: Springer; 1979.

28. Luvall JC, Kay JJ, Fraser RF. Thermal remote sensing and the thermodynamics of ecosystem development. In: Ulgiati S, Brown MT, Giampietro M, Herendeen RA, Mayumi K, editors. Advances in Energy Studies. Exploring Supplies, Constraints, and Strategies. Padova, Italy: SGEditoriali; 2001. pp. 147-158.

29. Aerts $R$, Wagendorp $T$, November $E$, Behailu M, Deckers J, Muys B. Ecosystem thermal buffer capacity as an indicator of the restoration status of protected areas in the Northern Ethiopian highlands. Restoration Ecology. 2004;12(4):586-596.

30. Maes WH, Pashuysen $T$, Trabucco $A$, Veroustraete F, Muys B. Does energy dissipation increase with ecosystem succession? Testing the ecosystem exergy theory combining theoretical simulations and thermal remote sensing observations. Ecological Modelling. 2011;222(23-24):3917-3941. 
31. Ulanowicz RE, Hannon BM. Life and the production of entropy. Proceedings of the Royal Society of London. 1987;232(1267):182-192.

32. Georgescu-Roegen N. The entropy law and economic process. Cambridge, MA, USA: Harvard University Press; 1971.

33. Volckaert F, Muys B. (Over)exploitatie van woud en zee. In: Waelkens S, Volckaert F, editors. Tijd voor biodiversiteit. Leuven, Belgium: Acco; 2000. pp. 104-119.

34. Daly HE. Beyond growth. The economics of sustainable development. Boston, MA, USA: Beacon Press; 1996.

35. Vitousek P, Mooney $\mathrm{H}$, Lubchenco J, Melillo J. Human domination of earth's ecosystems. Science. 1997;277(5325):494-499.

36. Barnosky $A D$, Hadly EA, Bascompte J, Berlow EL, Brown JH, Fortelius M, Getz WM, Harte J, Hastings A, Marquet PA, Martinez ND, Mooers A, Roopnarine $P$, Vermeij G, Williams JW, Gillespie R, Kitzes J, Marshall C, Matzke N, Mindell DP, Revilla $E$, Smith AB. Approaching a state shift in Earth's biosphere. Nature. 2012;486(7401):52-58.

37. Crutzen P. Geology of mankind. Nature. 2002;415(6867):23.

38. Daily G, editor. Nature's Services: Societal dependence on natural ecosystems. Washington, DC, USA: Island Press; 1997.

39. Millennium Ecosystem Assessment. Ecosystems and human well-being: Synthesis. Washington, DC, USA: Island Press; 2005.

40. TEEB. The Economics of Ecosystems and Biodiversity: Mainstreaming the Economics of Nature: A synthesis. City, Country: Publisher; 2010.

41. Norgaard RB. Ecosystem services: From eyeopening metaphor to complexity blinder. Ecological Economics. 2010;69(6):1219-1227.

42. Lovelock J. The Revenge of Gaia: Why the Earth Is Fighting Back-And How We Can Still Save Humanity. London, UK: Penguin Books Ltd.; 2006.

43. Thomas CD, Cameron A, Green RE, Bakkenes M, Beaumont LJ, Collingham YC, Erasmus BFN, Ferreira de Siqueira M, Grainger A, Hannah L, Hughes $L$, Huntley $B$, van Jaarsveld AS, Midgley GF, Miles $L$, Ortega-Huerta MA, Peterson AT, Phillips OL, Williams $\mathrm{SE}$. Extinction risk from climate change. Nature. 2004;427(6970):145-148.

44. Haberl $\mathrm{H}$. Human appropriation of net primary production as an environmental indicator: Implications for sustainable development. Ambio. 1997;26:143-146.

45. Lindeijer E. Biodiversity and life support impacts of land use in LCA. Journal of Cleaner Production. 2000;8(4):313-319.

46. Neumayer E. The human development index and sustainability-a constructive proposal. Ecological Economics. 2001;39(1):101-114.

47. Costanza R, Erickson J, Fligger K, Adams A, Altschul B, Balter S, Fisher B, Hike J, Kelly J, Kerr T, McCauley M, Montone K, Rauch M, Schmiedeskamp K,
Saxton D, Sparacino L, Tusinski W, Williams L. Estimates of the Genuine Progress Indicator (GPI) for Vermont, Chittenden County and Burlington, from 1950 to 2000. Ecological Economics. 2004;51(12):139-155.

48. Di Tella R, MacCulloch R. Gross national happiness as an answer to the Easterlin Paradox? Journal of Development Economics. 2008;86(1):22-42.

49. Rosen M. Can exergy help us understand and address environmental concerns. Exergy. 2002;2(4): 214-217.

50. Bendoricchio G, Jørgensen SE. Exergy as a goal function of ecosystem dynamic. Ecological Modeling. 1997;102(1):5-15.

51. Pueyo S. Irreversability and criticality in the biosphere. Barcelona, Spain: PhD Thesis, Department of Ecology, University of Barcelona; 2003.

52. Wagendorp T, Gulinck H, Coppin P, Muys B. Land use impact evaluation in life cycle assessment based on ecosystem thermodynamics. Energy. 2006;31(1):112-125.

53. Costanza $R$, d'Arge $R$, de Groot $R$, Farber $S$, Grasso M, Hannon B, Limburg K, Naeem S, O'Neill R, Paruelo J, Raskin R, Sutton $P$, van den Belt M. The value of the world's ecosystem services and natural capital. Nature. 1997;387(6630):253-260.

54. Rudel TK, Coomes OT, Moran E, Achard F, Angelsen A, Xu J, Lambin E. Forest transitions: towards a global understanding of the land use change. Global Environmental Change. 2005;15(1):23-31.

55. Meyfroidt $P$, Lambin EF. Forest transition in Vietnam and displacement of deforestation abroad. Proceedings of the National Academy of Sciences of the USA. 2009;106(38):16139-16144.

56. Garcia-Quijano J, Peters J, Cockx L, van Wyk G, Rosanov A, Deckmyn G, Ceulemans R, Ward SM, Holden NM, Van Orshoven J, Muys B. Carbon sequestration and environmental effects of afforestation with Pinus radiata D. Don in the Western Cape, South Africa. Climatic Change. 2007;83(3):323-355.

57. Heijungs RJ, Guinée J, Huppes G. Impact categories for natural resources and land use, report 138. Leiden, the Netherlands: Centre for Environmental Science, Leiden University; 1997.

58. Reid WV, Chen D, Goldfarb L, Hackmann H, Lee YT, Mokhele K, Ostrom E, Raivio K, Rockström J, Schellnhuber $\mathrm{HJ}$, Whyte A. Earth system science for global sustainability: Grand challenges. Science. 2010; 330(6006):916-917.

59. Kay J. Ecosystems as self-organizing holarchic open systems: Narratives and the second law of thermodynamics. In: Joergensen SE, Müller F, editors. Handbook of ecosystem theories and management. Boca Raton, FL, USA: CRC press, John Lewis Publishers; 2000. pp. 135-160.

60. Scheffer M, Carpenter S, Foley JA, Folke, C, Walker B. Catastrophic shifts in ecosystems. Nature. 2001;413(6856):591-596.

61. Gunderson L, Holling CS, editors. Panarchy: 
Understanding transformations in human and natural systems. Washington, DC, USA: Island Press; 2002.

62. Aerts R, November E, Hermy M, Deckers J, Haile $M$, Muys $B$. Assisting natural forest regeneration in Northern Ethiopia: One measure is not enough. Nature Precedings. 2008; doi:10.1038/npre.2008.2437.1.

63. Loorbach D. Transition management: New mode of governance for sustainable development. Utrecht, the Netherlands: International Books; 2007.

64. Homer-Dixon T. The upside of down, catas- trophe, creativity, and the renewal of civilization. Washington DC, USA: Island Press; 2006.

65. Boyd E, Folke C, editors. Adapting institutions. Governance, Complexity and Social-Ecological Resilience. Cambridge, UK: Cambridge University Press; 2012.

66. Fischer-Kowalski M, Rotmans J. Conceptualizing, observing, and influencing social-ecological transitions. Ecology and Society. 2009;14(2):3. 